
ветеринарної медицини та біотехнологій імені С.3. Гжицького

\author{
Scientific Messenger of Lviv National University \\ of Veterinary Medicine and Biotechnologies
}

\title{
Development of meat-containing semi-smoked sausages with Muscovy duck meat and white carp
}

\author{
N.V. Bozhko ${ }^{1}$, V.I. Tischenko ${ }^{1}$, V.M. Pasichnyi ${ }^{2}$, O. Antonenko ${ }^{1}$ \\ ${ }^{1}$ Sumy National Agrarian University, Sumy, Ukraine \\ ${ }^{2}$ National University of Food Technologies, Kyiv, Ukraine
}

Article info

Received 28.08.2018 Received in revised form 26.09 .2018 Accepted 27.09.2018

Sumy National Agrarian University, G. Kondratieva Str., 160, Sumy, 40021, Ukraine. Tel.: +38-054-270-11-43. E-mail:natalybozhko@ukr.net tischenko_1958@ukr.net

National University of Food Technologies, Volodumurska Str., 68, Kyiv, 01601, Ukraine. Tel.: +38-067-661-11-12 E-mail:pasww1@ukr.net
Bozhko, N.V., Tischenko, V.I., Pasichnyi, V.M., \& Antonenko, O. (2018). Development of meatcontaining semi-smoked sausages with Muscovy duck meat and white carp. Scientific Messenger of Lviv National University of Veterinary Medicine and Biotechnologies. 20(90), 12-16. doi: $10.32718 /$ nvlvet 9003

The article is devoted to the substantiation of expediency of combining white carp (Hypophthalmichthys molitrix) with Muscovy duck meat (Cairina moschata), grown in farms of the Sumy region. The recipes of meat-containing minced sausage systems for the production of meat-containing semi-smoked sausages have been developed. A complex of research of nutritional value and functional and technological indices of perfume systems and finished products was carried out. It was shown that the protein content in samples of meat- containing semi-smoked sausages increased by $4.00-5.16 \%$ and amounted to $16.75-16.93 \mathrm{~g} / 100 \mathrm{~g}$. The fat content of the developed samples of meat-containing semi-smoked sausages decreased for $41.40-50.92 \%$. The energy value of the prototype samples decreased and ranged from 212 to $241 \mathrm{kcal}$ per $100 \mathrm{~g}$, which is 32.30-40.45\% less compared to the analogue formulation. On the basis of the analysis of functional and technological indicators, the possibility of obtaining high functional and technological indicators of the model minced meat-containing semi-smoked sausages. The moisturebonding ability was in the range of $91.65-94.05 \%$, and wet-binding index - up to $51.69 \%$. The use of duck meat with freshwater fish does not negatively affect the physic-chemical parameters of finished semi-smoked sausages, and allows products with parameters that meet the standard to be obtained. Meat-containing semi-smoked sausages with Muscovy duck meat and white carp have high organoleptic characteristics. The conducted researches show that the developed recipes of meat and fish meatcontaining semi-smoked sausages can be recommended for production by enterprises of meat industry.

Key words: Muscovy duck meat, white carp, meat-containing semi-smoked sausages, recipes, functional and technological properties.

\section{Розробка м'ясо-містких напівкопчених ковбас з м'ясом качки мускусної та білого товстолобика}

\author{
Н.В. Божко ${ }^{1}$, В.І. Тищенко ${ }^{1}$, В.М. Пасічний르, В.О. Антоненко ${ }^{1}$ \\ ${ }^{1}$ Сумський національний аграрний університет, м. Суми, Украӥна \\ ${ }^{2}$ Національний університет харчових технологій, м. Київ, Украӥна
}

Стаття присвячена обтрунтуванню доцільності комбінування м'яса товстолобика білого (Нурорһthalmichthys тоlitrix) iз м'ясом качки мускусної (Cairina moschata), вирощених в господарствах Сумської області. Розроблені рецептури м'ясо-містких фаршевих систем для виготовлення м'ясо-містких напівкопчених ковбас. Проведений комплекс досліджень харчової цінності та функиіонально-технологічних показників фариевих систем та готової продукції. Показано, щчо вміст білка в зразках м'ясомістких напівкопчених ковбас збільшився на 4,00-5,16\% і становив 16,75-16,93 г/100 г. Вміст жиру в розроблених зразках м'ясомістких напівкопчених ковбас зменшився на 41,40-50,92\%. Енергетична цінність дослідних зразків зменшилась і коливалася від 212 до 241 кКал в 100 2, щчо на 32,30-40,45\% менше порівняно з рецептурою-аналогом. На підставі аналізу функиіональнотехнологічних показників підтверджено можливість отримання високих функціонально-технологічних показників модельних фаршів м'ясо-містких напівкопчених ковбас: В3За в межах 91,65-94,05\%, ВУЗ - до 51,69\%. Використання м'яса качки разом із м'ясом прісноводної риби не впливає негативно на фізико-хімічні показники готових напівкопчених ковбас, $і$ дозволяє отримати 
вироби із параметрами, щуо відповідають стандарту. М'ясо-місткі напівкопчені ковбаси із м'ясом качки мускусної та білого товстолобика мають високі органолептичні показники. Проведені дослідження показують, щзо розроблені рецептури м'ясорибних напівкопчених ковбас можуть бути рекомендовані до виробництва підприємствами м'ясної промисловості.

Ключові слова: м'ясо качки мускусної, м'ясо білого товстолобика, м'ясо-містка напівкопчена ковбаса, рецептури, функціонально-технологічні властивості.

\section{Вступ}

Повне та комплексне використання сировини основна тенденція у розвитку харчових технологій, особливо в умовах дефіциту харчового тваринного білка. Дуже ефективним способом оптимального використання харчової сировини є рибні та м'ясні фарші, на основі яких можливе формування полікомпонентних продуктів, регульованого хімічного складу і високої харчової та біологічної цінності.

Перспективною сировиною з точки зору білкового ресурсу у виробництві м'ясо-містких напівфабрикатів може бути ставкова риба регіонального виробництва. Інтерес до аквакультури як об'єкта переробки на харчові цілі виправданий відсутністю дефіциту сировини, можливістю іiі швидкого відновлення та нижчою ціновою вартістю порівняно 3 м'ясом забійних тварин. Суттєве значення також має адаптованість населення до цього виду сировини та висока збалансованість амінокислотного складу (Mohanty et al., 2014; Mohanty et al., 2017; Bozhko et al., 2018).

До регіональної сировини також відноситься м'ясо водоплавної птиці, котре раціонально використовувати у технологіях ковбасних виробів. Існує перспектива використання м'яса водоплавної птиці, що, на жаль, в Україні не набуло широкого розповсюдження, але це м'ясо за комплексом фізико-хімічних, функціонально-технологічних показників, харчової та біологічної цінності $\epsilon$ перспективною сировиною для м'ясної промисловості (Bozhko et al., 2016; Bozhko et al., 2018).

Для розширення асортименту якісної продукції вітчизняними та зарубіжними науковцями проводяться дослідження щодо застосування нетрадиційних поєднань сировини 3 метою створення комбінованих та функціональних продуктів харчування. Основою для розробки таких продуктів харчування може стати широке використання різних видів риби. Як в Україні, так і за іï межами проводиться дослідження щодо розробки рецептур комбінованих м'ясопродуктів із застосуванням різних видів рибної сировини (морської та прісноводної) та м'ясної регіонального походження.

М'ясо риби є важливим джерелом повноцінних білків (в середньому 14-12\%), високомолекулярних жирних кислот, що не синтезуються в організмі людини. Сировина рибного походження є також цінним джерелом мінеральних речовин та вітамінів (Tyshchenko et al., 2016).

Розглядаючи м'ясо риби як структурний компонент фаршевої системи, при виготовленні ковбасних виробів варто враховувати не лише кількість білків, а й їхні функціонально-технологічні властивості. До цих властивостей належать водо-та жирозв'язуюча здатність, рН та деякі інші. Міофібрилярні білки, що відносяться до солерозчинних та характеризуються повною біологічною повноцінністю вирізняються високою вологоутримуючою здатністю (ВУЗ). Високий вміст (порівняно з м'ясом сільськогосподарських тварин) гігроскопічних білків пояснює причину незначної втрати вологи під час термічної обробки риби, а також зумовлює високу соковитість та вихід готової продукції (Dvorjanynova and Antypova, 2012).

М'ясо качки - доступний продукт для населення України, який містить макромінеральні речовини в доступній формі. У м'ясі птиці наявні вітаміни А, Е, PР, групи В. Жир м'яса птиці має більше ненасичених жирних кислот, які не синтезуються організмом в достатній кількості, проте відіграють важливу роль в харчуванні людини. У ньому мало холестерину (Huda et al., 2011).

Для оптимізації кількості та якості інгредієнтів, що використовуються у виробництві комбінованих м'ясопродуктів, важливим залишається раціональний 3 точки зору ресурсозбереження підбір рецептурних складових тваринного походження. 3 цієї причини вивчення питань, пов'язаних з розробкою комбінованих м'ясо-містких виробів копченої групи на основі м'яса водоплавної птиці та прісноводної риби, є досить актуальним.

Метою досліджень є обгрунтування доцільності комбінування м'яса прісноводної риби, а саме товстолобика білого (Hуроphthalmichthys molitrix) із м'ясом качки мускусної (Cairina moschata), вирощених в господарствах Сумської області, у складі м'ясо-містких напівкопчених ковбас.

Для досягнення поставленої мети вирішувалися наступні завдання:

- дослідити можливість спільного використання м'яса качки і м'яса прісноводної риби в рецептурі м'ясо-містких напівкопчених ковбас;

- вивчити харчову та енергетичну цінність розроблених м'ясо-містких напівкопчених ковбас;

- вивчити функціонально-технологічні показники розроблених м'ясо-містких напівкопчених ковбас;

- провести оцінку сенсорних показників розроблених зразків м'ясо-містких напівкопчених ковбас.

\section{Матеріал і методи досліджень}

Для вирішення поставлених завдань як рецептура аналогу обрана напівкопчена ковбаса "Свиняча" (DSTU 4435:2005). Для виготовлення дослідних зразків використовували м'ясо качки мускусної (DSTU 3143:200). Фарш 3 м'яса качки готували за стандартною технологічною схемою. М'ясо качки обвалюють, знежиловують і подрібнюють на вовчку з діаметром отворів решітки 2-3 мм. Також до рецептур дослідних зразків ковбас вводили м'ясо білого товстолобика у вигляді фаршу.

Рецептурний склад основної сировини контрольного та дослідних зразків м'ясо-містких напівкопче- 
них ковбас наведений в таблиці 1. Виготовлення дослідних зразків ковбас проводили згідно з технологією виготовлення напівкопчених ковбас.

У модельних зразках м'ясо-містких напівкопчених ковбас досліджували харчову цінність готового про- дукту та визначали функціонально-технологічні показники модельних фаршів і готової продукції, проводили визначення сенсорних показників виробів за п'ятибальною шкалою згідно зі стандартними методиками (Kyshenko et al., 2010).

Таблиця 1

Рецептури дослідних зразків напівкопчених ковбас

\begin{tabular}{|c|c|c|c|c|}
\hline \multirow{2}{*}{ Складові компоненти фаршу } & \multicolumn{4}{|c|}{ Рецептури } \\
\hline & Контроль & 1 & 2 & 3 \\
\hline \multicolumn{5}{|c|}{ Основна сировина, кг на 100 кг несоленої сировини } \\
\hline Свинина напівжирна & 100 & - & - & - \\
\hline М’ясо качки мускусної & - & 70 & 60 & 50 \\
\hline Фарш рибний (товстолобик) & - & 30 & 40 & 50 \\
\hline Всього & 100 & 100 & 100 & 100 \\
\hline \multicolumn{5}{|c|}{ Допоміжна сировина, г на 100 кг несоленої сировини } \\
\hline Сіль кухонна & 2500 & 2500 & 2500 & 2500 \\
\hline Цукор & 90 & 90 & 90 & 90 \\
\hline Нітрит натрію & 5 & 5 & 5 & 5 \\
\hline Перець чорний & 60 & 60 & 60 & 60 \\
\hline Перець духмяний & 50 & 50 & 50 & 50 \\
\hline Часник свіжий подрібнений & 100 & 100 & 100 & 100 \\
\hline
\end{tabular}

Абсолютну похибку вимірювань визначали за допомогою критерію Стюдента, довірчий інтервал $\mathrm{P}=0,95$, кількість повторів у визначеннях 3-4, кількість паралельних проб дослідних зразків - 3 .

\section{Результати та їх обговорення}

Результати вивчення харчової та енергетичної цінності отриманого продукту наводяться в таблиці 2 .

3 табл. 2 видно, що вміст білка в рецептурі-аналозі становив 16,10 г/100 г продукту, тимчасом як в розроблених зразках м'ясо-містких напівкопчених ковбас цей показник не зменшився, а навіть збільшився на 4,00-5,16\% і становив 16,75-16,93 г/100 г. При цьому

\section{Таблиця 2}

Показники харчової цінності виробленої продукції

\begin{tabular}{lcccc}
\hline \multicolumn{1}{c}{ Найменування } & Контроль & Рецептура 1 & Рецептура 2 & Рецептура 3 \\
\hline Вміст білка, г/100 г & 16,10 & 16,93 & 16,84 & 16,75 \\
Вміст жиру, г/100 г & 32,80 & 19,22 & 17,56 & 16,10 \\
Енергетична цінність, ккал & 356,0 & 241,0 & 225,0 & 212,0 \\
\hline
\end{tabular}

\section{Таблиця 3}

Зміни фізико-хімічних показників модельних фаршів залежно від рецептур

\begin{tabular}{lcccc}
\hline \multicolumn{1}{c}{ Назва } & Вологість, $\%$ & В33, $\%$ & ВУ3, \% & $\mathrm{pH}, \%$ \\
\hline Контроль & $51,52 \pm 2,74$ & $94,05 \pm 6,89$ & $49,00 \pm 2,91$ & $6,21 \pm 0,05$ \\
Зразок 1 & $64,35 \pm 0,08$ & $93,82 \pm 1,26$ & $51,69 \pm 1,90$ & $6,41 \pm 0,08$ \\
Зразок 2 & $65,96 \pm 0,26$ & $92,60 \pm 0,40$ & $50,75 \pm 2,67$ & $6,50 \pm 0,01$ \\
Зразок 3 & $65,61 \pm 1,24$ & $91,65 \pm 0,83$ & $50,97 \pm 2,06$ & $6,74 \pm 0,01$ \\
\hline
\end{tabular}

Так, показник В33 а коливав в межах 91,65-94,05\%. Це пояснюється тим, що міофібрилярні білки риби разом з м'ясними білками качиного м'яса зв'язують та утримують воду на такому ж рівні, як напівжирна свинина. Отримані дані свідчать про стабілізацію показників дослідних фаршів, оскільки В33. для жод- для напівкопчених ковбас даний показник повинен бути не менше ніж 13\% (DSTU 4435:2005).

Вміст жиру в розроблених зразках м'ясо-місткої напівкопченої ковбаси був меншим, ніж в контролі. Загалом зниження масової частки жиру в дослідних зразках порівняно 3 контролем було нижчим і становило 16,1-19,22\%. Енергетична цінність дослідних зразків зменшилась і коливалася від 212 до 241 ккал в 100 г.

Для характеристики здатності отриманих модельних фаршів м'ясо-рибних напівкопчених ковбас зв'язувати вологу провели визначення показників вологозвязувальної здатності (В33а), вологоутримуючої здатності (ВУЗ), $\mathrm{pH}$ та загального вмісту вологи. Результати досліджень наведені в таблиці 1.

ної з рецептур не буває нижче за встановлений рівень $(85 \%)$.

У дослідних зразках спостерігається збільшення вмісту вологи та ВУЗ. Це відбувалося внаслідок внесення до рецептури рибного фаршу з білого товстолобика. Вологоутримуюча здатність контрольного фар- 
шу становить 49,00 $\pm 2,91 \%$, в дослідних зразках відмічено зростання цього показника на 3,57-5,48\%. Найвищим цей показник був у фарші за рецептурою № 1, що свідчить про найбільш оптимальне сполучення білкової сировини.

Також для показників В33 а для модельних фаршів має важливе значення величина активної кислотності, адже при зсуві значення рН від ізоелектричної точки ФТВ білків підвищуються. Даний показник для контрольного зразка складав $6,21 \pm 0,05$; для рецептур: № $1-6,41 \pm 0,08$; № $2-6,50 \pm 0,01$; № $3-6,74 \pm 0,01$ та узгоджувався 3 отриманими даними по В33. Основну роль у формуванні функціонально-технологічних властивостей фаршевих систем відіграють білки. Заміна м'ясних білків свинини білками мускусної качки та білого товстолобика не знижує, а в деяких випадках підвищує показники В33. дослідних зразків фаршів порівняно 3 контрольним. Це обумовлено високим ступенем їх гідратації.

У готових зразках м'ясо-містких напівкопчених ковбас було визначено вологість та $\mathrm{pH}$. Вологість та $\mathrm{pH}$ дослідних зразків показано на рисунку 1.

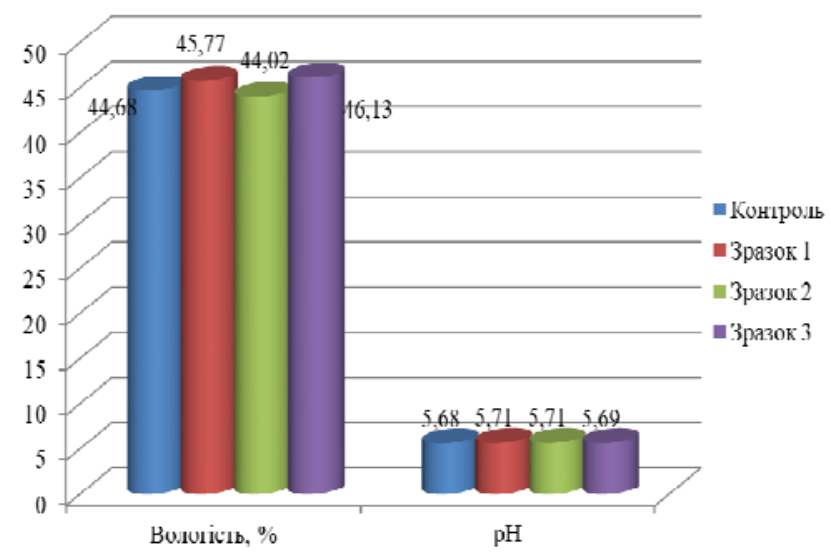

Рис. 1. Вологість та $\mathrm{pH}$ напівкопчених ковбас

Загальний вміст вологи в розроблених зразках становив 44,68-46,13\%. В дослідних зразках кількість води збереглася на тому ж рівні, що і в контрольному зразку із напівжирної свинини, тобто можна констатувати, що використання м'яса качки разом із м'ясом прісноводної риби не впливає на фізико-хімічні показники готових напівкопчених ковбас. Те саме можна сказати і про активну кислотність готових ковбас, яка становила 5,68-5,71, тобто була практично однаковою в усіх зразках.

На рис. 2 показана профілограма сенсорних показників виготовлених ковбас.

Сенсорну оцінку чотирьох зразків розроблених ковбас із м'ясом мускусної качки та м'ясом товстолобика проводили комісією $з$ десяти експертів, оцінюючи кожний показник за 5-баловою шкалою з використанням коефіцієнта вагомості кожного показника. Всі зразки ковбас відповідають вимогам стандарту за органолептичними показниками. Варто зазначити, що усі зразки досліджуваних м'ясо-містких напівкопчених ковбас отримали вищі оцінки порівняно 3 контрольним зразком. Зразки № 1-3 характеризувались приємним запахом, мали гарні смакові властивості і пружну консистенцію.

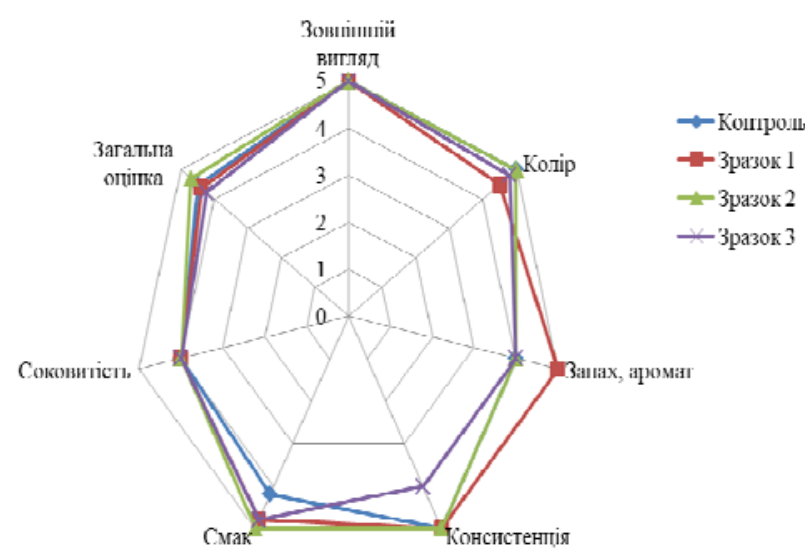

Рис. 2. Профілограма сенсорної оцінки виготовлених ковбас

Високу органолептичну оцінку отримали всі показники якості м'ясо-містких напівкопчених ковбас із м'ясом качки мускусної та товстолобика, проте варто відмітити, що найвищу оцінку отримав зразок № 2.

\section{Висновки}

1. Визначено, що при комбінуванні м'яса качки мускусної і м'яса білого товстолобика в складі м'ясомістких напівкопчених ковбас можливо виробляти повноцінні за харчовою цінністю продукти з високими якісними показниками.

2. Підтверджено можливість комбінування прісноводної риби і м'яса водоплавної птиці з одночасним збереженням високої харчової цінності м'ясо-містких ковбас, що виробляються за технологією напівкопчених ковбас та визначено показники їх енергетичної та харчової цінності.

3. На підставі аналізу функціональнотехнологічних показників підтверджено можливість отримання високих функціонально-технологічних показників модельних фаршів м'ясо-містких напівкопчених ковбас: В33а в межах 91,65-94,05\%, ВУЗ - до $51,69 \%$, чим доведено позитивний вплив спільного використання м'яса качки разом із м'ясом прісноводної риби на функціонально-технологічні показники напівкопчених ковбас 3 комбінованим складом сировини.

4. Підтверджено можливість досягнення високих показників сенсорної оцінки напівкопчених ковбас із м'ясом качки мускусної без використання традиційних видів м'ясної сировини.

Перспективи подальших досліджень. Напрямом подальших досліджень може бути вивчення біологічної цінності розроблених м'ясо-рибних напівкопчених ковбас та визначення економічної ефективності від впровадження їх у виробництво.

\section{References}

Mohanty, B.P., Mahanty, A., Ganguly, S., Mitra, T., Karunakaran, D., \& Anandan, R. (2017). Nutritional composition of food fishes and their importance in providing food and nutritional security. Food chemistry, 17, 12. doi: 10.1016/j.foodchem.2017.11.039. 
Bozhko, N.V., Tischenko, V.I., Pasichnyi, V.M., Yuschko, M.I., Zhukova, Ya., \& Popova, E. (2018). Study of functional and technological indices of meat-containing loaf with Muscovy duck meat and white carp. Scientific Messenger of Lviv National University of Veterinary Medicine and Biotechnologies, 20(85), 19-23. doi: 10.15421/nvlvet8504.

Mohanty, B., Mahanty, A., Ganguly, S. et al. (2014). Amino Acid Compositions of 27 Food Fishes and Their Importance in Clinical Nutrition. Journal of Amino Acids, 2014, 7-14. doi: 10.1155/2014/269797.

Bozhko, N., Tischenko, V., Pasichnyi, V., Polumbryk, M., \& Haschuk, O. (2018). The study of the possibility of combining freshwater fish with duck meat in meat-containing semi-finished products. EUREKA: Life Sciences, 4, 35-41. doi: 10.21303/25045695.2018.00682.

Bozhko, N.V., Pasichniy, V.M., Bordunova, V.V. (2016). Meat-containing cooked sausage containing the meat of a duck. Scientific Messenger LNUVMBT named after S.Z. Gzhytskyj, 18, 2(68), 143-146. doi: $10.15421 /$ nvlvet6829.
Tyshchenko, V.I., Bozhko, N.V., \& Pasichnyi, V.M. (2016). Rybnyi farsh yak syrovyna dlia vyrobnytstva polikomponentnykh produktiv kharchu-vannia. Zbirnyk naukovykh prats "Visnyk Kharkivskoho nats. tekhn. univ. s.h. im. Petra Vasylenka”. Kharkiv, 100 108 (in Ukranian).

Dvorjanynova, O.P., \& Antypova, L.V. (2012). Akvakuljturnye byoresursi: nauchnie osnovy y ynnovacyonnye reshenyja: monoghrafyja. Voronezh: VGhUYT (in Russian).

Huda, N., Putra, A., \& Ahmad, R. (2011). Potential Application of Duck Meat for Development of Processed Meat Products. Current Research in Poultry Science, 1(1), 1-11. doi: 10.3923/crpsaj.2011.1.11.

DSTU 4435:2005 (2006). Kovbasy napivkopcheni. Vydannia ofitsiine. Kyiv, Derzhspozhyvstandart Ukrayiny, 31 (in Ukranian).

DSTU 3143:200 (2013). Miaso ptytsi (tushky). Zahalni tekhnichni umovy. Kyiv, 42 (in Ukranian).

Kyshenko, I.I., Starchova, V.M., \& Honcharov, H.I. (2010). Tekhnolohiia miasa ta miasoproduktiv. Praktykum: navch. Posibnyk. Kyiv: NUKhT (in Ukranian). 